\title{
Surgical treatment of globe subluxation in the active phase of the myogenic type of Graves orbitopathy: case reports
}

\author{
Tratamento cirúrgico da subluxação do globo ocular na fase ativa do subtipo miogênico da \\ orbitopatia de Graves: relatos de casos
}

Felipe Eing ${ }^{1}$, Antonio Augusto Velasco e Cruz ${ }^{1}$

\begin{abstract}
The purpose of the present article is to present and discuss two cases of globe subluxation in the active phase of myogenic Graves' orbitopathy and to evaluate the prevalence of this phenomenon. Two patients with the myogenic variant of Graves orbitopathy that had being treated with oral and intravenous steroid pulses developed globe subluxation. Both had to have urgent eyelid and orbital decompression. Afte these observations, we reviewed the medical records of a sample of 284 patients (482 orbits) who had had orbital decompression at our Institution from 1992 to 2010 with a search for cases presenting severe proptosis or globe subluxation in the active phase of myogenic Graves' orbitopathy. No patient had to have decompression for globe subluxation in the active phase of Graves' orbitopathy. The prevalence of this event as an indication for surgery in the myogenic variant of Graves'orbitopathy was therefore $0.7 \%(2 / 284)$ or even less. The combination of lowering the upper eyelid and orbital decompression had a dramatic therapeutic effect on these patients despite the presence of intense inflammatory signs in the orbits. In conclusion, patients affected with the myogenic variant of Graves' orbitopathy may develop globe subluxation. Urgent surgical treatments should not be postponed despite the presence of active inflammation.
\end{abstract}

Keywords: Graves ophthalmopathy; Orbit/pathology; Exophthalmos/complications; Decompression, surgical; Tomography, X-ray; Humans; Male; Adult; Middle aged; Case reports

\begin{abstract}
RESUMO
O objetivo do presente trabalho é apresentar e discutir dois casos de subluxação do globo ocular na fase ativa do subtipo miogênico da orbitopatia de Graves e avaliar a prevalência desse fenômeno. Dois pacientes com o subtipo miogênico da orbitopatia de Graves tratados com corticosteroide oral e pulsos intravenosos desenvolveram subluxação do globo ocular. Após estas observações, analisamos os prontuários de uma amostra de 284 pacientes (482 órbitas) que foram submetidos à descompressão orbitária em nossa Instituição no período de 1992 a 2010, buscando os casos que apresentaram proptose severa ou subluxação do globo ocular na fase ativa da orbitopatia de Graves miogênica. Nenhum paciente tinha sido descomprimido para subluxação do globo ocular na fase ativa da orbitopatia de Graves. A prevalência desse evento como uma indicação para cirurgia na variante miogênica da orbitopatia de Graves foi 0,7\% (2/284) ou até menos. A combinação da correção da retração da pálpebra superior e da descompressão da órbita obteve um efeito terapêutico excelente nesses pacientes, apesar da intensa presença de sinais inflamatórios nas órbitas. Em conclusão, pacientes afetados com orbitopatia de Graves do subtipo miogênico podem desenvolver subluxação do globo. Tratamentos cirúrgicos de urgência não devem ser adiados apesar da presença de inflamação ativa.
\end{abstract}

Descritores: Oftalmopatia de Graves; Órbita/patologia; Exoftalmia/complicações; Descompressão cirúrgica; Tomografia por raios X; Humanos; Masculino; Adulto; Meia-idade; Relatos de casos

\section{INTRODUCTION}

Globe subluxation is defined as a sudden anterior displacement of the globe beyond the orbital rim ${ }^{(1)}$. It is an acute and painful event that generates considerable distress to affected patients. The optic nerve is tethered and corneal exposure ensues as the globe is continuously maintained outside the orbital limits by the combined action of eyelid retraction and orbicularis contraction (2).

Globe subluxation may occur in severe cases of exorbitism ${ }^{(3)}$, spontaneously in patients with shallow orbits and floppy eyelid syndro$m e^{(4)}$ or during eye manipulation such as contact lens insertion or eye examination ${ }^{(5)}$. Some individuals are able to voluntarily subluxate their eyes ${ }^{(6)}$. Other causes of globe subluxation include general anesthesia ${ }^{(7)}$, vomiting ${ }^{(8)}$ and retrobulbar space-occupying lesions ${ }^{(9)}$.

In Graves' orbitopathy (GO) eye subluxation is associated with the lipogenic pole of the disease which involves patients with almost normal extraocular muscles (EOM), increased volume of orbital fat and high degrees of proptosis ${ }^{(10)}$. In these patients the subluxation is transient and easily managed with manual eye repositioning ${ }^{(2)}$. Globe subluxation in the setting of the active phase of the myogenic type of $\mathrm{GO}$ is an extremely serious and different situation that is rarely mentioned in the ophthalmic literature. We are aware of just one of case reported in Israel|(11).

In the present article we report the results of urgent surgical treatment of two patients that presented with globe subluxation due to GO. Both had impressive inflammatory signs and EOM enlargement.

\section{METHODS}

We report an observational case series and retrospective follow-up study. We reviewed the medical records and computed tomography (CT) scans of all patients treated with bony orbital decompression surgery at our institution from 1992 and 2010. The sample consisted of 284 records (482 orbits) searching for patients who had to be decompressed in the active phase of the orbitopathy due to globe subluxation.
Funding: No specific financial support was available for this study Disclosure of potential conflicts of interest: F.Eing, None; A.A.V.Cruz, None.

Comitê de Ética em Pesquisa do Hospital das Clínicas de Ribeirão Preto - USP e da Faculdade de Medicina de Ribeirão Preto - USP - Ofício no 1823/2011. Processo no 11132/2008

Correspondence address: Antonio Augusto Velasco e Cruz. Hospital das Clínicas-Campus, Departamento de Oftalmologia, Otorrinolaringologia e Cirurgia de Cabeça e Pescoço. Av. Bandeirantes, 3900 - Ribeirão Preto (SP) - 14049-900 - Brazil - E-mails: aavecruz@fmrp.usp.br or felipeeing@hotmail.com 


\section{RESULTS}

Only 2 patients with globe subluxation in the active phase of GO had to be decompressed in our service during 18 years of experience with surgical treatment of GO.

\section{CASE 1}

A 42-year-old white man presented with a 5-month history of Graves' disease, complaining that his left eye had popped out of the orbit two months ago. He reported that at that time he started to feel pain, progressive swelling and an increasing difficulty in closing his left eye. The patient was previously treated with anti-thyroid drugs, beta-blockers, and oral and intravenous steroid pulse therapy without improvement.

On examination, the left eye was subluxated with its corneal surface covered by a thick white fibrinous membrane. (Figure 1). Visual acuity was 20/200 in the right eye and light perception in the left eye. Marked hyperemia, chemosis and keratopathy were evident in the right eye. Elevation was limited in the right eye. The left eye was frozen and its anterior segment was impossible to examine due to the conditions of the eye surface. The left eye was anesthetized and profusely irrigated with saline solution. The cornea then became visible, showing a white opacity consistent with incipient corneal melting. Exophthalmometry was estimated with a millimeter ruler to be $23 \mathrm{~mm}$ in the right and $39 \mathrm{~mm}$ in the left. Globe repositioning with manual maneuvers, cantholysis and Frost suture placement was unsuccessful. Orbital CT scans revealed a significant enlargement of the left EOM (Figure 2). On the same day, the patient underwent a simultaneous orbital decompression and bilateral blepharotomy combined with Müllerectomy plus recession of the levator muscle. Both orbits were inferomedially decompressed. The medial wall was accessed through the upper lid incision ${ }^{(12)}$. The floor was operated by a conventional transconjunctival approach. Postoperatively, the left eye was repositioned. The globe protrusion decreased $4 \mathrm{~mm}$ in the right eye and $19 \mathrm{~mm}$ in the left eye. His visual acuity improved to $20 / 40$ in the right eye and remained light perception in the left.

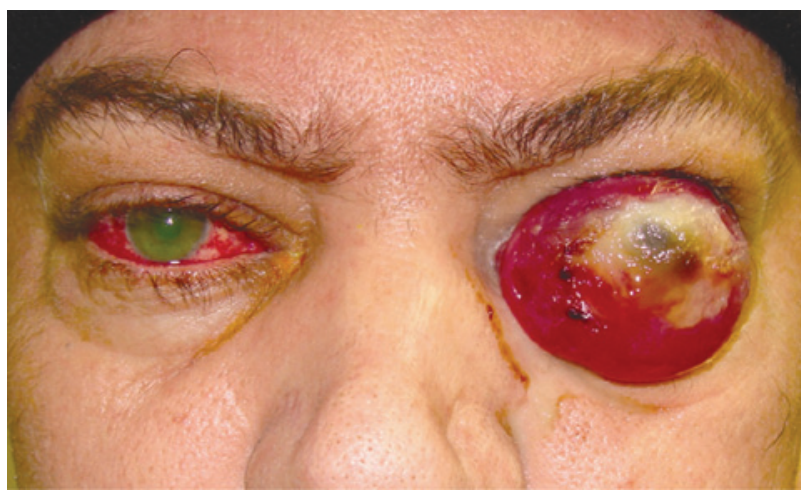

Figure 1. Left globe subluxation. The left cornea is covered by a white fibrinous membrane.

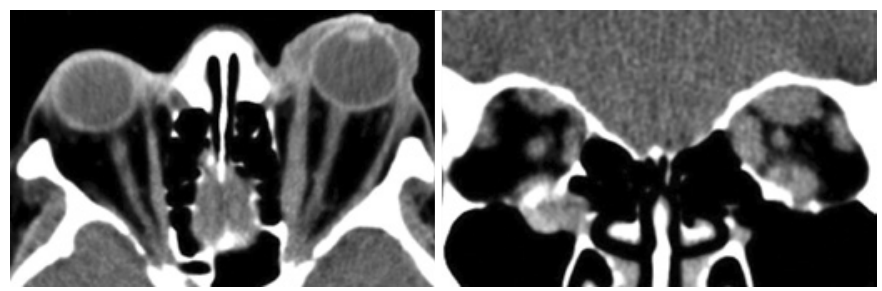

Figure 2. Axial (left) and coronal CT (right) scans of the patient. Note extraocular muscles involvement including the levator muscle and high position of the upper eyelid.
Four months after surgery the patient was treated with radiotherapy in both orbits and conjunctival coverage of the left cornea. A right reverse lower eyelid ptosis was corrected by shortening the lid retractors through an anterior approach. He is now stable (Figure 3).

\section{CASe 2}

A 60-year-old white man with Graves'disease and a 15-day history of bilateral globe subluxation was referred by a general ophthalmologist. Similar to case 1, the patient had been previously treated with anti-thyroid drugs, beta-blockers, and oral and intravenous steroid pulse therapy without improvement. On examination, both eyes were subluxated with marked chemosis and congestion and virtually no ocular motility (Figure 4). Visual acuity was hand motion in the right eye and light perception in the left. The left cornea was melting. Globe protrusion was estimated with a ruler to be around $40 \mathrm{~mm}$ in both eyes. Orbital CT scans demonstrated bilateral enlargement of the inferior and medial recti (Figure 5). He was admitted to the hospital and first underwent urgent temporary transverse blepharotomy and temporary tarsorraphy. The next day a bilateral three-wall orbital decompression was performed by a coronal approach.

After surgery, both eyes were repositioned. In order to control the orbital inflammatory activity, the patient was managed with oral steroids for a short period of time and with radiotherapy. Two months postoperatively his vision returned to 20/40 in the right eye and remained unchanged in the left. His final exophthalmometry measurements were $21 \mathrm{~mm}$ bilaterally (Figure 6).

\section{DISCUSSION}

With the exception of the cases which the globe is axially displaced by a retrobulbar expansile lesion, globe subluxation is widely

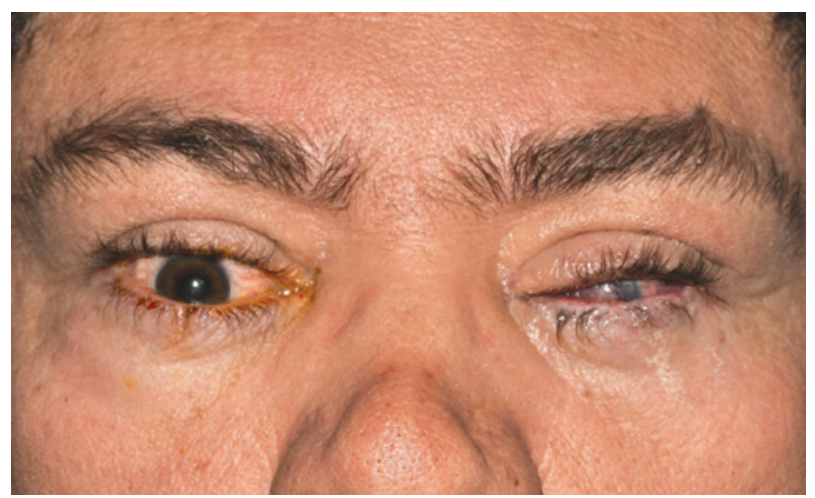

Figure 3. Clinical appearance after surgery.

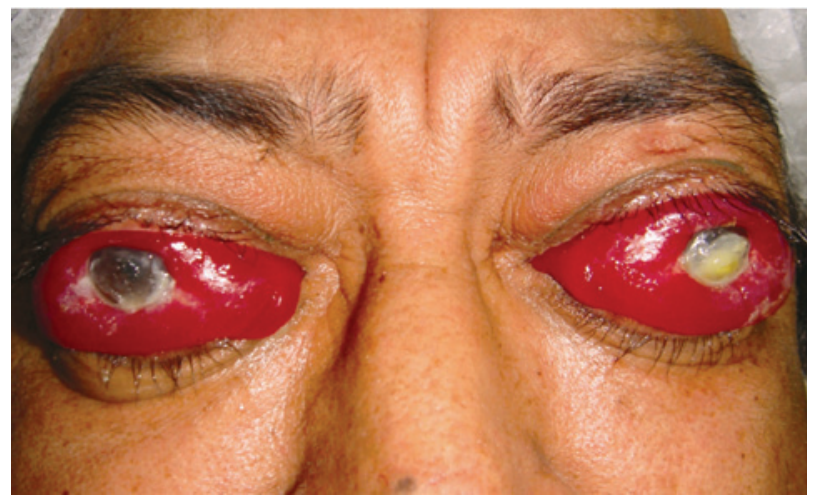

Figure 4. Bilateral globe subluxation in the inflammatory phase of GO. Note melting of the left cornea. 


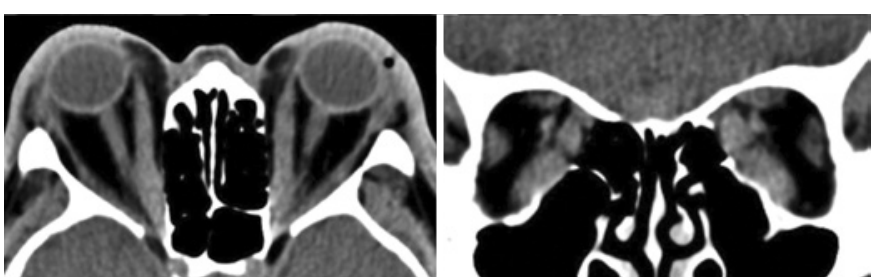

Figure 5. Axial (left) and coronal (right) CT scans showing extraocular muscles enlargement.

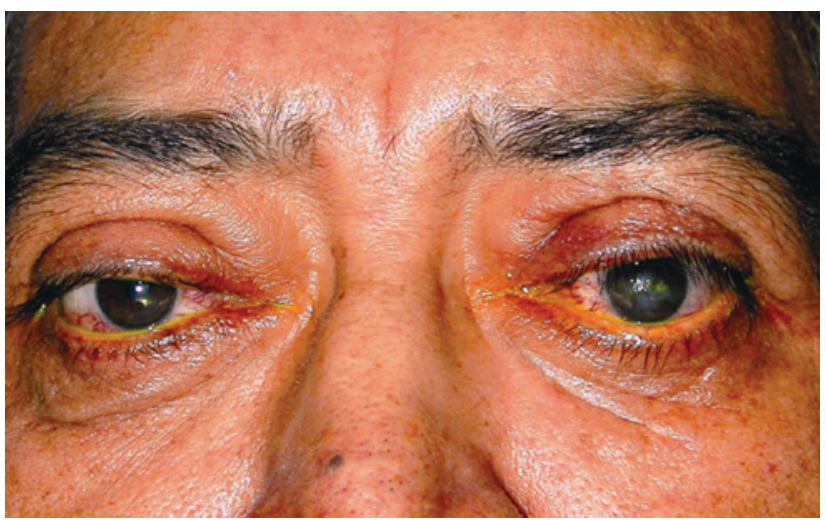

Figure 6. Clinical appearance after surgical treatment.

associated with shallow orbits, high orbital fat contents, normal compliance of the extraocular muscles, and floppy eyelids ${ }^{(10)}$. All these factors interact to allow the globe to be spontaneously or voluntarily displaced forward outside the orbital limits. The rare cases of globe subluxation in GO reported in the literature fit well this framework. The reported patients had the lipogenic variant of the disease and were in the inactive phase of the orbitopathy. Oculomotility was minimally impaired, demonstrating almost normal muscle compliance ${ }^{(10)}$.

Our cases were completely different. The two patients reported here and the third one reported in Israel were all in the active phase of the disease. Orbital CT scans showed marked EOM enlargement and severely impaired eye motility. The mechanisms of globe subluxation in these patients thus differ from those of previously reported cases. We believe that intense orbital inflammation associated with marked upper eyelid retraction due to levator muscle infiltration is capable to displace the eyeball even in the presence of rectus enlargement. In our cases the upper eyelids were fixed in a high position and globe repositioning was impossible without surgery.

Surgery in the setting of an intense orbital inflammation has not been evaluated. Conventional teaching advocates surgical treatment only for the inactive phase of the orbitopathy ${ }^{(13)}$. Our patients clearly could not wait for the efficacy of any alternative medical treatment. In both cases the combination of upper eyelid lowering with expansion of the bony orbit had a dramatic therapeutic effect and the inflammatory activity was not worsened by surgery. On the contrary, we observed a rapid decrease in their inflammatory signs. Although both patients required adjuvant radiotherapy for a complete control of disease activity we were pleased with the results of the surgical treatment. In cases of globe subluxation inflammatory activity is not a contraindication for surgery.

\section{REFERENCES}

1. Duke-Elder S. Displacements of the globe. In: Duke-Elder S. System of ophthalmology. London: Henry Kimpton; 1974. p.1233-4.

2. Tse DT. A simple maneuver to reposit a subluxed globe. Arch Ophthalmol. 2000; 118(3):410-1.

3. Havlik RJ, Bartlett SP. The treatment of "malignant" exorbitism with an extended supraorbital advancement. Plast Reconstr Surg. 1995;95(6):1094-7.

4. Alexandrakis G, Tse DT, Chang WJ. Spontaneous globe luxation associated with floppy eyelid syndrome and shallow orbits. Arch Ophthalmol. 1999;117(1):138-9. Comment in: Arch Ophthalmol. 1999;117(9):1266.

5. Kunesh JC, Katz SE. Spontaneous globe luxation associated with contact lens placement. CLAO J. 2002;28(1):2-4.

6. Apostolopoulos M, Papaspirou A, Damanakis A, Theodossiadis G, Moschos M. Bilateral optic neuropathy associated with voluntary globe luxation and floppy eyelid syndrome. Arch Ophthalmol. 2004:122(10):1555-6.

7. Clendenen SR, Kostick DA. Ocular globe luxation under general anesthesia. Anesth Analg. 2008;107(5):1630-1.

8. Zeller J, Murray SB, Fisher J. Spontaneous globe subluxation in a patient with hyperemesis gravidarum: a case report and review of the literature. J Emerg Med. 2007; 32(3):285-7.

9. Srinivasan S, Gaskell A, McWhinnie H, McClure JP, Corrigan N. Conservative management of globe luxation associated with congenital orbital venous anomaly. J Pediatr Ophthalmol Strabismus. 2003;40(3):170-1

10. Rubin PA, Watkins LM, Rumelt S, Sutula FC, Dallow RL. Orbital computed tomographic characteristics of globe subluxation in thyroid orbitopathy. Ophthalmology. 1998; 105(11):2061-4

11. Seider N, Miller B, Gilboa M, Beiran I. [Globe subluxation in thyroid orbitopathy. Harefuah. 2007;146:920-2, 1000]. Hebrew.

12. Cruz AA, Akaishi PM, Baccega A. Upper eyelid crease approach to the medial orbital wall. Plast Reconstr Surg. 2008;122(1):25e-26e

13. Wiersinga WM. Management of Graves' ophthalmopathy. Nat Clin Pract Endocrinol Metab. 2007;3(5):396-404.
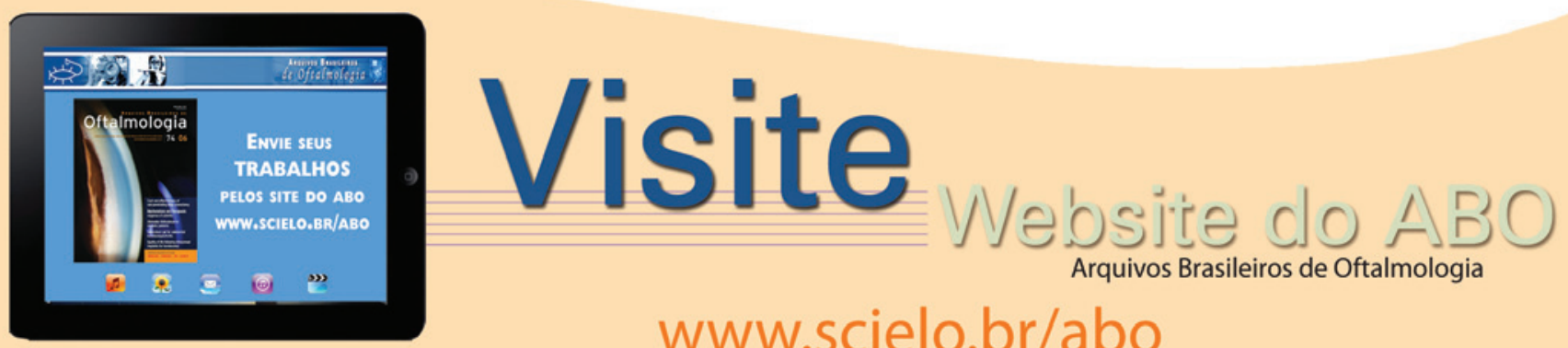
Arquivos Brasileiros de Oftalmologia

www.scielo.br/abo 